\title{
COMMENTARY
}

\section{Mathematical Ecology, Evolution, and the Social Sciences}

\author{
Simon A. Levin *
}

\begin{abstract}
The last few decades have seen an enhanced partnership between ecologists and social scientists, especially economists, in addressing the environmental challenges facing societies. Not only do ecology and economics, in particular, need each other; but also the challenges they face are similar and can benefit from cross-fertilization. At the core are scaling from the micro- to the macro, the development of appropriate statistical mechanics to facilitate scaling, features underlying the resilience and robustness of systems, the anticipation of critical transitions and regime shifts, and addressing the conflicts of interest between individual agents and the common good through exploration of cooperation, prosociality and collective decision-making. Confronting these issues will be crucial in the coming years for all nations, especially those in South Asia that will suffer in major ways from the consequences of overpopulation, climate change and other environmental threats.
\end{abstract}

Keywords: Mathematical Ecology and Evolution; Economics; Public Goods; Scaling; Complex Adaptive Systems.

\section{INTRODUCTION}

Though my academic training was as an applied mathematician, I was drawn even as a graduate student to problems in biology, especially in ecology. I received my Ph.D. in 1964, two years after the appearance of Rachel Carson's monumental Silent Spring and just a few years before the influential Population Bomb of Paul and Anne Ehrlich (Carson 1962; Ehrlich 1968). In this context of increasing societal attention to environmental

\footnotetext{
* James S. McDonnell Distinguished University Professor, Department of Ecology and Evolution, Princeton University, Princeton, New Jersey 08544-1003; slevin@princeton.edu.

Copyright (C) Levin 2021. Released under Creative Commons Attribution-NonCommercial 4.0 International licence (CC BY-NC 4.0) by the author.

Published by Indian Society for Ecological Economics (INSEE), c/o Institute of Economic Growth, University Enclave, North Campus, Delhi 110007.
}

ISSN: 2581-6152 (print); 2581-6101 (web).

DOI: https://doi.org/10.37773/ees.v4i1.401 
degradation, I was increasingly drawn to studying the environment, and, by 1970 , I was fully committed to the field of ecology, and in particular the development of theoretical foundations.

Theoretical ecology is a subject that is at least a century old. Its earlier roots, going back several centuries, were in demography and the biology of populations, spurred on by the need for more quantitative approaches to these subjects. The first fundamental mathematical advances were made by the great mathematician Vito Volterra and the physical chemist and mathematician Alfred Lotka, who independently derived sets of differential equations to describe the dynamics of species in competition and exploitation (Lotka 1925; Volterra 1926). Volterra, in particular, was interested in the fluctuations of the Adriatic fisheries, a problem brought to him by Umberto d'Ancona, a formidable fisheries biologist, and his simple equations were able to explain those fluctuations. The equations of Lotka and Volterra still are at the core of much work in theoretical ecology today and have found application in economics and other social sciences (Samuelson 1971, 1974).

I enjoyed pure theoretical ecology and still do; but I soon realized that to address environmental issues substantively, I needed to turn more effectively towards economics and other social sciences. The key issues that needed to be addressed included how to value biodiversity and convince others of that value; matters of discounting the future, equity, and the interests of others; and the role of cooperation and social norms in the development of management strategies in local and global commons. Thirty years ago, I was invited to join the nascent Beijer Institute at the Swedish Academy of Sciences, and that interdisciplinary paradise changed my research trajectory, and those of countless others, forever. I learned how much ecology needed economics and how much economics needed ecology, and the collaborations that followed have been invaluable.

However, I also learned something else. The problems of ecology and economics are two sides of the same coin; this is no accident, because both disciplines address the self-organization and evolution of communities of individual agents competing, exploiting, and cooperating with emergent dynamics at higher levels of organization that produce systems that cycle various kinds of capital, natural and created, and provide a context in which individual behaviours change. Kenneth Arrow, one of the key members of the Beijer community, pointed out to us that the fact that both disciplines begin with "eco-," meaning household, was not coincidence; they both face similar issues-both confront complex adaptive systems (CAS) and the challenges of understanding and managing them (Arrow, Ehrlich, and Levin 2014). 


\section{SOME COMMON PROBLEMS IN ECOLOGY AND ECONOMICS}

Because similar problems have been addressed in both disciplines, there are reciprocal benefits from revisiting the different approaches that have been developed in the two. Such mutualisms are increasing in number, and I will touch on only a few of them in this section. These include but are not limited to the matter of scaling across levels and across space and time (Chave and Levin 2003); foraging theory and search theory (Pyke, Pulliam, and Charnov 1977); the potential for critical transitions (Steele 1998; Scheffer 2009); and identifying the structural features that make systems robust and resilient (Holling 1973; Levin et al. 1998; Levin and Lubchenco 2008).

Evolutionary ecology to a large extent addresses how genomes have been adapted to deal with uncertain environments. The vertebrate immune system is a wonderful example of evolution's hierarchical response to the certainty of uncertain events and is a model for how societies might deal with everything from pandemics to terrorist attacks to financial collapse (Levin and Lo 2015). More generally, life history theory in evolution deals in large part with the allocation of resources over an evolutionary lineage (Stearns 1992) and has strong parallels with models of the theory of interest (Haberler and Fisher 1931) and of resource allocation and dynasty theory in economics (Becker 1965; Heckman 2015). Kenneth Arrow and I merged these by examining through dynamic programming how uncertainty of various kinds would affect consumption patterns and deferral of resources to one's offspring, a fundamental problem in evolution and economics alike (Arrow and Levin 2009).

More generally, evolution deals with fitnesses and the processes that select more fit genotypes over less fit ones, while economics does the same, with the word "fitnesses" replaced by "utilities". Both ecology and economics therefore utilize techniques from optimization and game theory to understand what strategies can be expected to prevail; indeed, crossfertilization between the two perspectives on such problems is rapidly gaining traction.

\section{COMPLEX ADAPTIVE SYSTEMS}

Ecological systems, the socio-economic systems with which they interact, and the interconnected global socio-ecological system that emerge, are all examples of CAS (Holland 1995; Levin 1998, 1999; Arrow, Ehrlich, and Levin 2014). Such systems are composed of individual agents that interact 
with one another at local scales, leading to the emergence of higher order patterns and processes that feed back to modify individual behaviours. The agents-be they genomes, organisms, institutions, or nations-adapt their behaviours, in some cases over evolutionary time, generally in response to differential payoffs, utilities, or fitnesses; hence, the term "adaptive" in the name. The term, however, can be misleading, since the myopic benefits to individuals may not advance the collective good; the adaptation is at levels below the whole system.

Whatever the natures of the CAS, similar questions arise: What factors underlie the robustness and resilience of these systems to change, exogenous or endogenous? Are there early warning indicators of impending transitions? How do patterns vary across scales, and how can we use coarse-grained models to understand the emergent properties as statistical consequences of behaviours and interactions among large numbers of agents? And perhaps most challenging, how do conflicts between the interests of individual agents and the collective good play out, and to what extent do they undermine equity or system resilience?

These are, of course, all familiar challenges to economists, who are used to dealing with the interplay between microeconomics and macroeconomics and with the challenges of public goods and common-pool resources. It might be surprising, however, for economists to learn that such questions, especially of cooperation in the face of public goods, are at the centre of much evolutionary theory. Bacteria produce extracellular polymers that provide collective benefits as well as antibiotics that poison susceptible neighbours; plants fix nitrogen, transforming it into a form more widely available to free-riders; and species from cellular slime moulds to birds, fish, and humans engage in collective behaviours that improve access to resources or mutual defence. All involve costs and all are susceptible to free-riding. Understanding how and under what conditions such behaviours are maintained, and when they break down (as in tumour growth), are among the deepest problems in evolutionary theory-puzzles that worried Charles Darwin enough to delay publication of The Origin of Species for many years.

\section{PUBLIC GOODS, COMMON-POOL RESOURCES, AND THE TRAGEDY OF THE COMMONS}

Our planet is threatened by a litany of interlocking problems-climate change, biodiversity loss, overpopulation, and increasing inequity-that must be solved if we are to achieve a sustainable future. William Forster Lloyd first spoke of the commons nearly two centuries ago (Lloyd 1833), 
and Garrett Hardin famously introduced the notion of the "tragedy of the commons, arguing that the solution was in "mutual coercion, mutually agreed upon" (Hardin 1968). Views about managing the commons were changed, however, by the landmark work of another core Beijer participant, Elinor Ostrom, who showed, through empirical and theoretical arguments, that societies could self-regulate through the development of social norms and other institutions that limited overexploitation (Ostrom 1990). Dealing with the commons is at the centre of the partnership that must grow between biology and the social sciences in the coming decades. Economists have with great success developed frameworks for dealing with public goods by addressing questions such as: What is the social optimum? Without top-down regulation, can the social optimum be approximated and sustained as a Nash equilibrium or does discounting of the future undermine it? Where it cannot be sustained, are there second-best solutions that can be? In cooperative games, can co-operators develop social norms, for example, the punishment of defectors, that can flip the system to more favourable equilibria? What is the role of prosociality and how can it be achieved (Gintis 2003; Akcay et al. 2009; Dixit, Levin, and Rubenstein 2013; Dixit and Levin 2017)? Evolutionary biologists have had to tackle the same problems from different perspectives, focusing attention on the evolution of altruism and cooperation and the importance of genetic relatedness (Hamilton and Axelrod 1981; Nowak, Tarnita, and Wilson 2010; Levin, 2014). We now need to bring these separate approaches together to develop a theory of governance for the global commons. (Polasky et al. 2019). Ostrom's ideas of polycentric governance (Ostrom 2009) are likely to play a central role in what must be at the top of the agenda for ecological and environmental ecologists for many years to come.

\section{CONCLUDING THOUGHTS}

The problems discussed in this paper are, of course, of general relevance to all nations, but they pose special challenges for India and other parts of South Asia. Overpopulation, biodiversity loss, and the growing inequity in well-being are especially acute in these parts of the world, as documented in the Dasgupta report for the British government on the economics of biodiversity (H M Treasury 2020). Infectious diseases, like the current COVID-19 pandemic, threaten devasting consequences. Climate change will impact India, China, Pakistan, and Bangladesh especially hard, and expanding populations and their resource needs will exacerbate the climate crisis, unless steps towards promoting alternative energy are successful. It is no surprise then that there has been increasing attention on implementing decarbonization as rapidly as possible, especially in India and China, and in 
addressing the social norms issues that will be crucial to people's willingness to accept it. Thus, the marriage of ecology, economics, and other social sciences is especially crucial in South Asia and stands to benefit enormously from the efforts of the readers of this journal. I hope this call to action will find enthusiastic acceptance.

\section{REFERENCES}

Akcay, E., J. Van Cleve, M. W. Feldman, and J. Roughgarden. 2009. "A Theory for the Evolution of Other-Regard Integrating Proximate and Ultimate Perspectives." Proceedings of the National Academy of Sciences of the United States of America (PNAS) 106 (45): 19061-66. https://doi.org/10.1073/pnas.0904357106.

Arrow, K. J., P. R. Ehrlich, and S. A. Levin. 2014. "Some Perspectives on Linked Ecosystems and Socio-Economic Systems." In Environment and Development Economics: Essays in Honor of Sir Partha Dasgupta, edited by S. Barrett, K-G. Mäler, and E. S. Maskin, 95-116. Oxford: Oxford University Press. https://doi.org/10.1093/acprof:oso/9780199677856.003.0003

Arrow, K. J., and S.A. Levin. 2009. "Intergenerational Resource Transfers with Random Offspring Numbers." PNAS 106 (33): 13702-13706.

https://doi.org/10.1073/pnas.0905613106.

Becker, G. S. 1965. "A Theory of the Allocation of Time." The Economic Journal 75 (299): 493-597. https://doi.org/10.2307/2228949.

Carson, R. 1962. Silent Spring. Boston: Houghton Mifflin.

Chave, J., and S. A. Levin. 2003. "Scale and Scaling in Ecological and Economic Systems." Environmental and Resource Economics, 26: 527-57. https://doi.org/10.1023/B:EARE.0000007348.42742.49

Dixit, A., and S. A. Levin. 2017. "Social Creation of Pro-Social Preferences." In The Theory of Externalities and Pubic Goods, edited by Wolfgang Buccholz and Dirk

Rubbelke, 127-43. Cham: Springer Nature. https://doi.org/10.1007/978-3-31949442-5 7.

Dixit, A. K., S. A. Levin, and D. I. Rubenstein. 2013. "Reciprocal Insurance among Kenyan Pastoralists." Theoretical Ecology 6 (2): 173-87.

https://doi.org/10.1007/s12080-012-0169-x.

Ehrlich, P. R. 1968. The Population Bomb. New York: Ballantine Books.

Gintis, H. 2003. "Solving the Puzzle of Prosociality." Rationality and Society 15 (2):

155-87. https://doi.org/10.1177/1043463103015002001

H. M. Treasury. 2020. The Dasgupta Review - Independent Review on the Economics of Biodiversity Interim Report. London: H M Treasury. https://www.gov.uk/government/publications/interim-report-the-dasguptareview-independent-review-on-the-economics-of-biodiversity.

Haberler, G., and I. Fisher. 1931. "Irving Fisher's 'Theory of Interest."” The Quarterly Journal of Economics 45 (3): 499-516. https://doi.org/10.2307/1883901. 
Hamilton, W. D., and R. Axelrod. 1981. “The Evolution of Cooperation.” Sciences 211 (4489): 1390-96. https://doi.org/10.1126/science.7466396.

Hardin, G. 1968. "The Tragedy of the Commons.” Sciences 162: 1243-48.

https://doi.org/10.1126/science.162.3859.1243.

Heckman, J. J. 2015. "Introduction to A Theory of the Allocation of Time by Gary Becker." The Economic Journal 125 (583): 403-9.

https://doi.org/10.1111/ecoj.12228.

Holland, J. 1995. Hidden Order. How Adaptation Builds Complexity. Reading, MA: Addison Wesley.

Holling, C. S. 1973. "Resilience and Stability of Ecological Systems." Annual Review of Ecology and Systematics 4: 1-23.

https://doi.org/10.1146/annurev.es.04.110173.000245.

Levin, S. A. 1998. "Ecosystems and the Biosphere as Complex Adaptive Systems." Ecosystems 1: 431-36. https://doi.org/10.1007/s100219900037

Levin, S. A. 1999. Fragile Dominion: Complexity and the Commons. Reading, MA: Perseus Books.

Levin, S. A. 2014. "Public Goods in Relation to Competition, Cooperation, and Spite.” PNAS 111: 10838-45. https://doi.org/10.1073/pnas.1400830111.

Levin, S. A., and A. Lo. 2015. "Opinion: A New Approach to Financial Regulation.” PNAS 112 (41): 12543-44.

https://doi.org/10.1073/pnas.1518385112

Levin, S. A., S. Barrett, S. Aniyar, W. Baumol, C. Bliss, B. Bolin, P. Dasgupta, et al. 1998. "Resilience in Natural and Socioeconomic Systems." Environment and Developmental Economics 3: 225-36. https://doi.org/10.1017/S1355770X98240125.

Levin, S. A., and J. Lubchenco. 2008. "Resilience, Robustness, and Marine Ecosystem-Based Management.” BioScience 58 (1): 27-32.

https://doi.org/10.1641/B580107.

Lloyd, W. F. 1833. Two Lectures on the Checks to Population. Oxford: Oxford University Press.

Lotka, A. J. 1925. Elements of Physical Biology. Reprint, Baltimore, MD: Williams and Wilkins.

Nowak, M. A, C. E. Tarnita, and E. O. Wilson. 2010. "The Evolution of Eusociality." Nature 466 (7310): 1057-62. https://doi.org/10.1038/nature09205.

Ostrom, E. 1990. Governing the Commons: The Evolution of Institutions for Collective Action. Cambridge: Cambridge University Press. https://doi.org/10.1017/CBO9780511807763

2009. "A Polycentric Approach for Coping with Climate Change." World Bank Policy Research Working Paper 5095. Washington D.C.: The World Bank.

Polasky, S., C. L. Kling, S. A. Levin, S. R. Carpenter, G. C. Daily, P. R. Ehrlich, G. M. Heal, and J. Lubchenco. 2019. "Role of Economics in Analyzing the Environment and Sustainable Development.” PNAS 116 (12): 5233-5238. https://doi.org/10.1073/pnas.1901616116. 
Pyke, G. H., H. R. Pulliam, and E. L. Charnov. 1977. “Optimal Foraging Selective Review of Theory and Tests." Quarterly Review of Biology 52 (2): 137-54. https://doi.org/10.1086/409852.

Samuelson, P. A. 1971. "Generalized Predator-Prey Oscillations in Ecological and Economic Equilibrium.” PNAS 68 (5): 980-83.

https://doi.org/10.1073/pnas.68.5.980. 1974. "A Biological Least Action Principle for the Ecological Model of Volterra-Lotka.” PNAS 71 (4): 3041-44. https://doi.org/10.1073/pnas.71.8.3041. Scheffer, M. 2009. "Critical Transitions in Nature and Society.” Princeton: Princeton University Press. https://doi.org/10.1515/9781400833276

Stearns, S. C. 1992. The Evolution of Life Histories. Oxford: Oxford University Press. Steele, J. H. 1998. "Regime Shifts in Marine Ecosystems.” Ecological Applications 8: S33-36. https://doi.org/10.1890/1051-0761(1998)8[S33:RSIME]2.0.CO;2.

Volterra, V. 1926. "Variazioni e Fluttuazioni Del Numero d'individui in Specie Animale Conviventi." Mem R Accad Nazionale Del Lincei (Ser. 6) 2: 31-113. 